\title{
SANKCJE ZA NIEPRAWIDŁOWE WYDATKOWANIE FUNDUSZY UNII EUROPEJSKIEJ - REKONSTRUKCJA STANU PRAWA I ORZECZNICTWA ${ }^{1}$
}

\section{Wprowadzenie}

Wydatkowanie funduszy publicznych nieodłącznie wiąże się z ryzykiem, że zaangażowane $\mathrm{w}$ to podmioty naruszą przepisy określające warunki korzystania ze wsparcia. Jeżeli do naruszenia prawa dojdzie w toku wydatkowania funduszy pochodzących z budżetu Unii Europejskiej (funduszy UE), wynikające stąd konsekwencje określa prawo unijne. Zawarte w nim przepisy zobowiązują organy krajowe państw członkowskich do odzyskiwania kwot pieniężnych wydatkowanych z naruszeniem prawa oraz do nakładania kar administracyjnych i karnych, a orzekając je, państwa członkowskie stosują przepisy unijne i przepisy krajowe. Relatywnie duża liczebność norm prawnych dotyczących zwrotu kwot pieniężnych i ustalających kary, ich nie zawsze jasne sformułowania oraz zachodzące między nimi relacje powodują, że wybór właściwej podstawy prawnej może rodzić trudności. Dowodzi tego kazuistyczne orzecznictwo Trybunału Sprawiedliwości Unii Europejskiej (TSUE) w sprawach, w których sądy krajowe zwracały się do niego z wnioskiem o wyjaśnienie mających zastosowanie reguł.

Niniejsze opracowanie zmierza do rekonstrukcji zasad sformułowanych w przepisach unijnych $\mathrm{i}$ w orzecznictwie TSUE, stosowanych przez organy krajowe państw członkowskich $\mathrm{w}$ przypadku naruszenia prawa $\mathrm{w}$ toku wydatkowana funduszy UE. Skupia się na dwóch zagadnieniach prawnych. Po pierwsze na podstawie prawnej stosowanej dla dochodzenia przez organy krajowe zwrotu kwot pieniężnych wydatkowanych $\mathrm{z}$ naruszeniem prawa. $\mathrm{W}$ tym obszarze kluczowe jest wskazanie charakteru prawnego obowiązku zwrotu, który - jak przyjmuje TSUE - nie stanowi 
sankcji. Po drugie przedstawiona zostanie problematyka podstaw prawnych właściwych dla nakładania przez organy krajowe kar administracyjnych, które, jak wynika z judykatury unijnej, w świetle zasady ustawowej określoności czynów zabronionych i kar, muszą być jasne i precyzyjne.

\section{Ramy prawne}

Na poziomie prawa unijnego przepisy dotyczące zwrotu kwot pieniężnych wydatkowanych przez jednostki z naruszeniem prawa i nakładanych na nie za to kar administracyjnych określają: horyzontalne rozporządzenie $\mathrm{nr} 2988 / 95^{2}$ oraz rozporządzenia sektorowe, przyjmowane w ramach tych polityk UE, w których dokonywane są płatności pokrywane z budżetu UE.

Rozporządzenie nr 2988/95, jak wyjaśnia jego art. 1 ust. 1, ustala ogólne zasady dotyczące kontroli, środków administracyjnych i kar orzekanych w wyniku nieprawidłowości, aby - na co wskazuje motyw 3 jego preambuły - we wszystkich dziedzinach przeciwstawiać się działaniom przynoszącym szkodę interesom finansowym Unii. Rozporządzenie to definiuje pojęcie nieprawidłowości, którą jest jakiekolwiek naruszenie prawa UE powodujące lub mogące spowodować szkodę w budżecie UE (art. 1 ust. 2 rozporządzenia nr 2988/95). Centralnym punktem definicji nieprawidłowości jest - jak odnotowała rzecznik generalna (RG) J. Kokott ${ }^{3}$, naruszenie przepisu wspólnotowego (unijnego - przyp. Autorki ${ }^{4}$ ) i wynikająca z niego ewentualna szkoda w budżecie Unii. W przypadku popełnienia nieprawidłowości, państwa członkowskie zobowiązane są odzyskiwać kwoty pieniężne wydatkowane z naruszeniem prawa. Artykuł 4 rozporządzenia nr 2988/95 określa obowiązek odzyskiwania bezprawnie uzyskanej korzyści mianem „środka administracyjnego" i wyraźnie zastrzega, że nie stanowi ono kary. Jeżeli jednak nieprawidłowości zostaną popełnione celowo lub wskutek zaniedbania, państwa członkowskie mogą nakładać kary administracyjne na osoby, które je popełniły, uczestniczyły w nich, lub na których ciążył obowiązek poniesienia odpowiedzialności za nie lub obowiązek zapobiegania im. Artykuł 5 rozporządzenia nr 2988/95 zawiera katalog kar administracyjnych, zaliczając do nich: karę pieniężną, zapłatę kwoty większej od kwoty uzyskanej, odebranie korzyści, utratę zabezpieczenia lub depozytu i inne. Rozporządzenie zastrzega, że jego przepisy nie wpływają na kompetencje państw członkowskich w zakresie prawa karnego, które są wykonywane wyłącznie przez te państwa (motyw 12 preambuły rozporządzenia nr 2988/95). Akt ten określa też termin prze-

Rozporządzenie Rady (WE, Euratom) nr 2988/95 z dnia 18 grudnia 1995 r. w sprawie ochrony interesów finansowych Wspólnot Europejskich (Dz. Urz. UE L 312 z 23.12.1995, s. 1, polskie wydanie specjalne rozdz. 1, t. 1, s. 340).

Zob. opinia rzecznik generalnej J. Kokott z dnia 15 lipca 2010 r. do sprawy C-367/09 SGS Belgium NV, pkt 40. W opracowaniu stosowana będzie terminologia wprowadzona na mocy Traktatu z Lizbony, na podstawie którego Unia Europejska uzyskała podmiotowość międzynarodową i zastąpiła Wspólnotę Europejską. 
dawnienia nieprawidłowości, którego upływ wyklucza możliwość stosowania środków i kar administracyjnych, a także relacje pomiędzy postępowaniami prowadzonymi na jego podstawie a postępowaniami karnymi oraz przepisy dotyczące kontroli. Ustalono w nim, że szczegółowe przepisy dotyczące środków administracyjnych i sankcji zostaną przyjęte w unijnych przepisach sektorowych, a przepisy te mają być z nim zgodne (motyw 5. preambuły rozporządzenia nr 2988/95), natomiast w zakresie nieuregulowanym prawem unijnym państwa członkowskie stosują przepisy krajowe.

Odnosząc się do unijnych przepisów sektorowych, jako do drugiej grupy norm zobowiązujących państwa członkowskie do odzyskiwania kwot pieniężnych wydatkowanych nieprawidłowo i stosowanych w takim przypadku kar administracyjnych, warto zauważyć, że blisko $80 \%$ wydatków z budżetu UE finansuje wdrażanie Wspólnej Polityki Rolnej (WPR) i polityki spójności. Stąd też na szczególną uwagę zasługują przepisy przyjęte w ramach obu tych polityk. Reguły określające zasady wdrażania WPR i polityki spójności są sformułowane w podobny sposób. Ogólnie ustalają je rozporządzenia dotyczące finansowania tych polityk (w okresie programowania 2013-2020 sa to: w przypadku WPR - rozporządzenie nr 1306/20135, w odniesieniu zaś do polityki spójności - rozporządzenie nr 1303/20136). Szczegółowe reguły implementacji tych polityk ustalają rozporządzenia odnoszące się do określonych, realizowanych w ich ramach obszarów (np. refundacji wywozowych, płatności obszarowych, etc.). Polityki te różni przyjęta metoda regulacji problematyki kar administracyjnych. O ile bowiem w ramach WPR od wielu już lat ustalane są szczegółowe przepisy określające kary administracyjne grożące za określonego rodzaju naruszenia prawa UE i stosowane w tym celu wymogi proceduralne (zob. art. 77, art. 97-100 rozporządzenia nr 1306/2013 i projekt rozporządzenia delegowanego Komisji ${ }^{7}$ ), o tyle tego rodzaju przepisy, co do zasady, nie są przyjmowane w ramach polityki spójności. Oznacza to, że kary stosowane za naruszenia przepisów polityki spójności są w głównej mierze ustalane na poziomie krajowym, przez państwa członkowskie.

5 Rozporządzenie Parlamentu Europejskiego i Rady (UE) nr 1306/2013 z dnia 17 grudnia 2013 w sprawie finansowania wspólnej polityki rolnej, zarządzania nią i monitorowania jej oraz uchylające rozporządzenia Rady (EWG) nr 352/78, (WE) nr 165/94, (WE) nr 2799/98, (WE) nr 814/2000, (WE) nr 1290/2005 i (WE) nr 485/2008 (Dz. Urz. UE L 347 z 20.12.2013 r., s. 549).

6 Rozporządzenie Parlamentu Europejskiego i Rady (UE) nr 1303/2013 z dnia 17 grudnia 2013 r. ustanawiające wspólne przepisy dotyczące Europejskiego Funduszu Rozwoju Regionalnego, Europejskiego Funduszu Społecznego, Funduszu Spójności, Europejskiego Funduszu Rolnego na rzecz Rozwoju Obszarów Wiejskich oraz Europejskiego Funduszu Morskiego i Rybackiego oraz ustanawiające przepisy ogólne dotyczące Europejskiego Funduszu Rozwoju Regionalnego, Europejskiego Funduszu Społecznego, Funduszu Spójności i Europejskiego Funduszu Morskiego i Rybackiego oraz uchylające rozporządzenie Rady (WE) nr 1083/2006 (Dz. Urz. L 347 z 20.12.2013 r., s. 320).

$7 \quad$ Projekt rozporządzenia delegowanego Komisji z dnia 11 marca 2014 r. uzupełniającego rozporządzenie Parlamentu Europejskiego i Rady (UE) nr rozporządzenia nr 1306/2013 w odniesieniu do zintegrowanego systemu zarządzania i kontroli oraz warunków odmowy lub wycofania płatności oraz do kar administracyjnych mających zastosowanie do płatności bezpośrednich, wsparcia rozwoju obszarów wiejskich oraz zasady wzajemnej zgodności (C(2014) 1459 final). 


\section{Zwrot kwot pieniężnych}

Z utrwalonego orzecznictwa TSUE wynika, że obowiązek zwrotu funduszy UE wydatkowanych z naruszeniem prawa nie stanowi sankcji, lecz ,jest jedynie konsekwencją ustalenia, że warunki wymagane dla uzyskania korzyści, wynikające z przepisów wspólnotowych, zostały stworzone w sposób sztuczny, co powoduje uznanie przyznanej korzyści za nienależną i w konsekwencji uzasadnia obowiązek jej zwrotu" ". Jak stwierdził TSUE na gruncie przepisów dotyczących WPR, jeżeli prawodawca Unii ustanawia przesłanki warunkujące przyznanie pomocy, to wykluczenie spowodowane niespełnieniem jednej z nich nie stanowi sankcji, lecz jest zwykłą konsekwencją nieprzestrzegania wymogów przewidzianych prawem9. Podobnie wyjaśnił to RG N. Jääskinen ${ }^{10} \mathrm{w}$ sprawie dotyczącej odmowy poddania się przez podmioty korzystające z pomocy UE kontrolom, które miały być przeprowadzone przez organy krajowe. Stwierdził, że jeżeli zachowania lub bezczynność kontrolowanych podmiotów uniemożliwiły organowi krajowemu przeprowadzenie skutecznej kontroli umożliwiającej sprawdzenie przesłanek wymaganych dla jej uzyskania, to organ krajowy może żądać jej zwrotu, a zwrot ten nie stanowi sankcji w rozumieniu art. 6 ust. 2 rozporządzenia $\mathrm{nr} 4045 / 89^{11}$. Analogiczny pogląd TSUE przyjął na gruncie unii celnej i wspólnotowego kodeksu celnego ${ }^{12}$, gdy uznał, że obowiązek zwrotu nienależnej korzyści, uzyskanej poprzez praktykę uchybiającą prawu, nie narusza zasady praworządności. Obowiązek ten - jak wyjaśnił TSUE - nie jest bowiem sankcją, lecz jedynie konsekwencją ustalenia, że warunki wymagane dla uzyskania korzyści wynikającej z przepisów UE zostały stworzone w sposób sztuczny, co powoduje uznanie przyznanej korzyści za nienależną i w konsekwencji uzasadnia obowiązek jej zwrotu.

Z założenia, że obowiązek zwrotu funduszy UE wydatkowanych w wyniku nieprawidłowości nie stanowi sankcji, Sąd (dawny Sąd Pierwszej Instancji) wyprowadził niedawno wniosek, wyrażony w sprawie T-297/05 IPK International ${ }^{13}$, że

Tak w wyroku Sądu z dnia 15 kwietnia 2011 r. w sprawie T-297/05 IPK International - World Tourism Marketing Consultants $\mathrm{GmbH}$ p. Komisji, Zb. Orz. 2011, s. Il-1859, pkt 117. Zob. też Wyroki Trybunału: z dnia 13 marca 2008 r. w połączonych sprawach C-383/06 do C-385/06 Vereniging Nationaal Overlegorgaan Sociale Werkvoorziening (C-383/06) i Gemeente Rotterdam (C-384/06) p. Minister van Sociale Zaken en Werkgelegenheid $i$ Sociaal Economische Samenwerking West-Brabant (C-385/06) p. Algemene Directie voor de Arbeidsvoorziening, Zb. Orz. 2008, s. l-1561, pkt 39; z dnia 14 grudnia 2000 r. w sprawie C-110/99 Emsland-Stärke GmbH, ECR 2000, s. I-11569, pkt 56 .

9 Wyroki Trybunału: z dnia 24 maja 2007 r. w sprawie w sprawie C45/11 Maatschap SchonewillePrins, Zb. Orz., s. I3997, pkt 47; z dnia 24 maja 2012 r. w sprawie C188/11 Hehenberger, pkt 37 (niepublikowany); z dnia 13 grudnia 2012 r. w sprawie C-670/11 FranceAgriMer, pkt 64 (niepublikowany).

10 Opinia rzecznika generalnego Niila Jääskinena z dnia 14 marca 2013 r. w sprawie C3/12 Syndicat OP 84, pkt 73 .

11 Rozporządzenie Rady (EWG) nr 4045/89 z dnia 21 grudnia 1989 r. w sprawie kontroli przez Państwa Członkowskie transakcji stanowiących część systemu finansowania przez Sekcję Gwarancji Europejskiego Funduszu Orientacji i Gwarancji Rolnej i uchylające dyrektywę 77/435/EWG (Dz. U. WE L 388 z 30.12.1989 r., s. 18, polskie wydanie specjalne rozdz. 3, tom 9, s. 208).

12 Wyrok Trybunału z dnia 4 czerwca 2009 r. w sprawie C-158/08 Agenzia Dogane Ufficio delle Dogane di Trieste p. Pometon SpA., Zb. Orz. 2009, s. I-4695, pkt 28-29.

13 Wyrok Sądu z dnia 15 kwietnia 2011 r. w sprawie T-297/05 IPK International - World Tourism Marketing Consultants GmbH p. Komisji, Zb. Orz. 2011, s. II-1859, pkt 117-118. Zob. też: wyrok Sądu Pierwszej Instancji z dnia 20 
Sankcje za nieprawidłowe wydatkowanie funduszy Unii Europejskiej...

właściwą i wystarczającą podstawą prawną dla odzyskania kwot pieniężnych jest art. 4 rozporządzenia nr 2988/95. Artykuł ten, jak wspomniano w pkt 2 opracowania, zatytułowany ,środek administracyjny” stanowi, że każda nieprawidłowość pociąga za sobą z reguły cofnięcie bezprawnie uzyskanej korzyści, poprzez zobowiązanie do zapłaty lub zwrotu kwot pieniężnych należnych lub bezprawnie uzyskanych, i nie stanowi to kary. Sąd przyjął, że art. 4 rozporządzenia nr 2988/95 urzeczywistnia na poziomie prawa wtórnego zasadę ogólną prawa unijnego, z której wynika, że organy administracyjne są upoważnione do cofnięcia z mocą wsteczną korzystnego aktu administracyjnego, który przyjęto bezprawnie, również $\mathrm{w}$ razie braku konkretnych przepisów w tym względzie. Tezy te pozwoliły Sądowi na konkluzję, że w przypadku, gdy w decyzji o cofnięciu wsparcia nie zawarto żadnego przepisu, który mógłby stanowić podstawę prawną tego aktu, to podstawą dochodzenia zwrotu jest art. 4 rozporządzenia nr 2988/95.

Powyżej wskazana teza, wyrażona w sprawie T-297/05 IPK International przyjmująca, że art. 4 rozporządzenia nr 2988/95 stanowi właściwą i wystarczającą podstawę prawną dla odzyskania kwot pieniężnych wydatkowanych w wyniku nieprawidłowości odbiega od dotychczasowego orzecznictwa TSUE, w którym uznawał on, że właściwą w tym celu podstawę stanowią przepisy sektorowe. Orzekł tak między innymi w wyroku w połączonych sprawach C-383/06 do C-385/06 Vereniging Nationaal Overlegorgaan Sociale Werkvoorziening ${ }^{14}$ dotyczącym odzyskiwania kwot pieniężnych wydatkowanych nieprawidłowo w ramach polityki spójności. Stwierdził w nim, że to sektorowe rozporządzenie $\mathrm{nr} 4253 / 88^{15}$, a nie rozporządzenie nr 2988/95, stanowi właściwą podstawę prawną dla obowiązku odzyskania przez państwa członkowskie funduszy utraconych w następstwie nadużycia lub niedbalstwa, i bez konieczności stosowania przepisów krajowych. Wyjaśnił przy tym, że rozporządzenie nr 2988/95 wprowadza jedynie ogólne reguły kontroli oraz sankcji w celu ochrony finansowych interesów Unii.

Różne rozstrzygnięcia w sprawach T-297/05 IPK International oraz C-383/06 do C-385/06 Vereniging Nationaal Overlegorgaan Sociale Werkvoorziening można próbować wyjaśnić specyfiką ich ram prawnych. W sprawie T-297/05 IPK International nie istniały bowiem przepisy sektorowe, które mogłyby być zastosowane w celu odzyskania kwot wydatkowanych z naruszeniem prawa. Stąd też - jak można zakładać - Sąd uznał, że właściwą i wystarczającą w tym celu podstawą prawną jest art. 4 rozporządzenia nr 2988/95. W przypadku braku szczegółowego przepisu

listopada 2002 r. w sprawie T-251/00 Lagardère SCA i Canal+ SA p. Komisji, ECR, s. II-4825, pkt 138-140.

Wyrok Trybunału z dnia 13 marca 2008 r. w połączonych sprawach C-383/06 do C-385/06 Vereniging Nationaal Overlegorgaan Sociale Werkvoorziening (C-383/06) i Gemeente Rotterdam (C-384/06) p. Minister van Sociale Zaken en Werkgelegenheid i Sociaal Economische Samenwerking West-Brabant (C-385/06) p. Algemene Directie voor de Arbeidsvoorziening, Zb. Orz. 2008, s. I-1561, pkt 39-40.

15 Council Regulation (EEC) No $4253 / 88$ of 19 December 1988, laying down provisions for implementing Regulation (EEC) No 2052/88 as regards coordination of the activities of the different Structural Funds between themselves and with the operations of the European Investment Bank and the other existing financial instruments (OJ L 374 of 31.12.1988, p. 1) (brak wersji polskiej). 
sektorowego Sąd zastosował przepis ogólny, który - co podkreślił - urzeczywistnia na poziomie prawa wtórnego zasadę ogólną prawa UE stanowiącą, że korzystny, lecz bezprawnie przyjęty akt administracyjny może być cofnięty również $\mathrm{w}$ razie braku konkretnych przepisów w tym względzie. Inaczej rzecz wyglądała w sprawie C-383/06 do C-385/06 Vereniging Nationaal Overlegorgaan Sociale Werkvoorziening, w której Trybunał mógł przytoczyć przepis sektorowego rozporządzenia nr 4253/88 z zakresu polityki spójności nakazujący państwom członkowskim odzyskiwać kwoty pieniężne wydatkowane z naruszeniem prawa, co też uczynił.

\section{Kary administracyjne}

Z orzecznictwa TSUE wynika, że o ile w przypadku braku przepisów sektorowych, art. 4 rozporządzenia nr 2988/95 stanowi właściwą i wystarczającą podstawę prawną dla odzyskiwania funduszy UE wydatkowanych z naruszeniem prawa, o tyle ustalony w nim art. 5, zawierający katalog kar administracyjnych, nie może być podstawą prawną dla nakładania kar (sankcji). Tezę tę TSUE przypomniał ostatnio w sprawie C-670/2011 FranceAgriMer ${ }^{16}$, w odpowiedzi na pytanie sądu francuskiego o to, czy na spółkę, która z naruszeniem przepisów rozporządzenia nr $1059 / 83^{17} \mathrm{~W}$ sprawie wspólnej organizacji rynku wina uzyskała pomoc za składowanie moszczów gronowych, może być nałożona kara administracyjna na podstawie art. 5 rozporządzenia nr 2988/95, jeżeli przepisy sektorowe jej nie ustalały. Trybunał taką możliwość wykluczył, lecz uznał, że bezprawnie uzyskana pomoc podlega zwrotowi na podstawie art. 4 rozporządzenia nr 2988/95 (zob. pkt 3 opracowania).

Przytoczona w sprawie C-670/2011 FranceAgriMer teza, że art. 5 rozporządzenia nr 2988/95 nie może stanowić podstawy prawnej nałożenia kary administracyjnej została sformułowana w sprawie C-369/09 SGS Belgium ${ }^{18}$. Dotyczyła ona kary pieniężnej nałożonej przez organ krajowy na SGS Belgium, spółkę wyspecjalizowaną w dziedzinie kontroli i nadzoru. Spółka ta dostarczyła firmie Derwa (eksporterowi) świadectwo poświadczające nieprawdziwą informację, że wołowina wywieziona przez eksportera do Egiptu została wprowadzona w tym państwie do obrotu, co warunkowało uzyskanie przez niego refundacji wywozowej. Po tym jak eksporter uzyskał refundację, belgijskie organy wykryły, że dokument wystawiony przez spółkę SGS Belgium, konieczny dla wypłaty refundacji poświadczał nieprawdę i zażądały od tej spółki zapłaty kwoty ponad 4,5 mln euro, odpowiadającej wysokości refundacji wywozowej uzyskanej nienależnie przez eksportera i kary pieniężnej ustalonej

16 Wyroki Trybunału: $z$ dnia 13 grudnia 2012 r. w sprawie C-670/11 FranceAgriMer, (niepublikowany), pkt 50. centrated grape must and rectified concentrated grape must (OJ L 116 of 30.04.1983, p. 77) (brak wersji polskiej). Wyrok Trybunału z dnia 28 października 2010 r. w sprawie C-367/09 SGS Belgium NV, Zb. Orz. 2010, s. I-10761, pkt 43. 
w art. 11 rozporządzenia nr 3665/8719. Ponieważ artykuł ten ustalał kary nakładane na eksportera, którym spółka SGS Belgium koniec końców nie była, sąd belgijski, rozpatrujący odwołanie od decyzji nakładającej tę karę, powziął wątpliwość co do jej podstawy prawnej. Alternatywnie rozważał możliwość nałożenia na spółkę SGS Belgium kary albo na podstawie art. 11 rozporządzenia nr 3665/87, albo też w oparciu o art. 5 rozporządzenia nr 2988/95. Przywołał też przepisy belgijskiego dekretu królewskiego, które przewidywały, że spółki takie jak SGS Belgium, zaangażowane w czynności wywozu, ponoszą odpowiedzialność solidarną z innymi stronami za finansowe skutki wystawianych świadectw.

W odpowiedzi na pytanie sądu belgijskiego Trybunał wykluczył obie rozważane przez niego możliwości. Pierwszą, ze względu na precyzyjne sformułowanie zakresu podmiotowego norm sankcjonujących ustalonych w art. 11 rozporządzenia nr 3665/87, które mogły być stosowane wyłącznie względem eksporterów. Drugą, gdyż jak stwierdził TSUE, art. 5 rozporządzenia nr 2988/95 w ogóle nie może być podstawą nakładania kar. Stwierdził, że choć zgodnie z art. 288 TFUE rozporządzenia $\mathrm{z}$ reguły wywołują bezpośredni skutek w krajowych porządkach prawnych, wprowadzenie w życie niektórych $\mathrm{z}$ nich może wymagać przyjęcia środków wykonawczych przez prawodawcę unijnego lub władze krajowe, a sytuacja ta zachodzi w przypadku kar administracyjnych, o których stanowi art. 5 rozporządzenia nr 2988/95. Powołując się na opinię RG J. Kokott ${ }^{20}$ TSUE wskazał na niedookreślony charakter zawartych w nich sformułowań. Odnotował, że po pierwsze artykuł ten stanowi, iż nieprawidłowości popełnione celowo lub wskutek zaniedbania jedynie „mogą” prowadzić do nałożenia określonych w nim kar administracyjnych, orzekanie ich nie jest zatem obowiązkowe. Po drugie przepis ten nie określa, które z wymienionych w nim rodzajów kar administracyjnych należy stosować do określonych kategorii nieprawidłowości, ani nie wskazuje też podmiotów, na które miałyby być nakładane. W rezultacie TSUE uznał, że art. 5 rozporządzenia nr 2988/95 ustalający kary administracyjne jest niejasny i nieprecyzyjny, co wyklucza możliwość stosowania go jako podstawy do orzekania sankcji. Jego niedookreślony charakter stanowi zresztą cechę charakterystyczną rozporządzenia nr 2988/95, na co wskazują zawarte w nim art. 2 ust. 3 odczytywane w zw. z motywami 5-8 preambuły. Stanowią one, że rozporządzenie to ma określić ogólne zasady mające zastosowanie do przepisów sektorowych, które w obszarze kar powinien przyjąć prawodawca unijny na kształt tych, które w momencie jego przyjmowania obowiązywały w ra-

19 Rozporządzenie Komisji (EWG) nr 3665/1987 z dnia 27 listopada 1987 r. ustanawiające wspólne szczegółowe zasady stosowania systemu refundacji wywozowych do produktów rolnych (Dz. Urz. WE L 351 s. 1). Legalność sankcji ustanowionych w art. 11 rozporządzenia $\mathrm{nr}$ 3665/87 stanowiła przedmiot odesłania prejudycjalnego złożonego przez sąd niemiecki i rozstrzygnięta przez Trybunał w wyroku z dnia 24 kwietnia 2008 r. w sprawie C-143/2007 AOB Reuter, Zb. Orz. 2008, s. I-03171pkt 34. W wyroku tym TSUE po stwierdzeniu, że artykuł ustalający tę sankcję jest jasny i w wystarczający sposób uzasadnia stosowanie sankcji uznał, że nie narusza on zasady legalności i pewności prawa. 20 Rzecznik generalna wręcz nazwała te przepisy „czysto uznaniowymi”. Zob. opinia rzecznik generalnej J. Kokott
z dnia 15 lipca 2010 r. do sprawy C-367/09 SGS Belgium NV, pkt 40. 
mach WPR. Ponadto, z art. 2 ust. 4 rozporządzenia nr 2988/95 wynika, że w zakresie nieuregulowanym prawem unijnym środki i kary administracyjne oraz stosowane procedury kontrolne podlegają prawu państw członkowskich ${ }^{21}$. Rozważania te doprowadziły TSUE do konkluzji, sugerowanej zresztą w opinii RG J. Kokott ${ }^{22}$, że możliwość zastosowania art. 5 rozporządzenia nr 2988/95 jako podstawy prawnej orzekania przez organy krajowe kar administracyjnych wyklucza zasada ustawowej określoności czynów zabronionych i kar. Choć w omawianym wyroku TSUE nie przybliżył tej zasady, jej znaczenie można zrekonstruować na podstawie jego dorobku orzeczniczego.

Zasada ustawowej określoności czynów zabronionych i kar (nullum crimen, nulla poena sine lege), zwana również zasadą legalności kar ${ }^{23}$, została sformułowana w orzecznictwie TSUE w latach 80. XX w., w sprawach 117/83 Köneck ${ }^{24} i$ 137/85 Mä̈zena $^{25}$ i na stałe wpisała się w jego judykaturę ${ }^{26}$. Trybunał przyjmuje, że zasada ustawowej określoności czynów zabronionych i kar stanowi szczególną postać ogólnej zasady pewności prawa, która jest podstawową zasadą prawa unijnego i wywodzi się z tradycji konstytucyjnych wspólnych dla państw członkowskich. Omawiana zasada, wyrażona w różnych umowach międzynarodowych, w szczególności w art. 7 ust. 1 Europejskiej Konwencji Praw Człowieka, wymaga, by przepisy definiujące czyny zabronione i grożące za nie kary były jasne i precyzyjne, tak by podlegające im podmioty prawa mogły ustalić swoje prawa i obowiązki w sposób jednoznaczny oraz podjąć w związku z tym odpowiednie kroki. Warunek ten jest spełniony, jeśli zainteresowany podmiot na podstawie treści przepisu $\mathrm{i} \mathrm{w}$ razie potrzeby na podstawie wykładni dokonanej przez sądy, jest w stanie określić, jakie działania i zaniechania grożą pociągnięciem go do odpowiedzialności karnej ${ }^{27}$. TSUE odwołuje się do zasady ustawowej określoności czynów zabronionych i kar nie tylko na gruncie prawa karnego, z którego zasada ta się wywodzi, ale również w innych obszarach prawa UE. I tak, na gruncie przepisów z zakresu WPR Trybunał wielokrotnie przypominał, że sankcja, nawet niemająca charakteru karnego, może być orzekana je-

21 TSUE przypomniał też regułę sformułowaną w latach 80. XX w. w znanej sprawie greckiej kukurydzy (wyrok Trybunału z dnia 21 września 1989 r. w sprawie 68/88 Komisja p. Grecji, ECR, s. 2965, pkt 23; podobnie wyrok Trybunału z dnia 8 lipca 1999 r. w sprawie C-186/98 Nunes i de Matos, ECR s. I-4883, pkt 12 i 14). Stwierdził wówczas, że jeżeli przepisy Unii nie zawierają żadnego postanowienia przewidującego sankcję na wypadek jego naruszenia, którą stosować mają państwa członkowskie lub przewidują możliwość stosowania sankcji, lecz nie określają ich w sposób wyczerpujący, art. 4 ust. 3 TUE zobowiązuje państwa członkowskie do podjęcia wszelkich skutecznych środków sankcjonujących zachowania, które naruszają interesy finansowe Unii. Opinia rzecznik generalnej J. Kokott z dnia 15 lipca 2010 r. do sprawy C-367/09 SGS Belgium NV, pkt 35-40. Wyrok Sądu z dnia 17 maja 2011 r. w sprawie T-299/08 Elf Aquitaine SA p. Komisji, Zb. Orz. 2011, s. II-2149, pkt 187.

Wyrok Trybunału z dnia 25 września 1984 r. w sprawie 117/83 Karl Köneck, ECR 1984, s. 3291, pkt 11. Wyroki Trybunału z dnia 18 listopada 1987 r. w sprawie 137/85 Maizena, ECR 1987, s. 4587.

Wyroki Trybunału: z dnia 3 maja 2007 r. w sprawie C-303/05 Advocaten voor de Wereld VZW, Zb. Orz. 2007, s. I-3633, pkt 48-50; z dnia 12 grudnia 1996 r. w sprawach połączonych C-74/95 i C-129/95 X, ECR s. I-6609, pkt 25; z dnia 28 czerwca 2005 r. w sprawach połączonych C-189/02 P, C-202/02 P, od C-205/02 P do C-208/02 P i C-213/02 P Dansk Rørindustri i in. p. Komisji, ECR s. I-5425, pkt 215-219.

Wyroki Trybunału: z dnia 3 czerwca 2008 r. w sprawie C308/06 Intertanko i in., Zb.Orz. s. 14057, pkt 70-71; z dnia 3 maja 2007 r. w sprawie C303/05 Advocaten voor de Wereld, Zb.Orz. s. I3633, pkt 50. 
dynie pod warunkiem, że opiera się na jasnej i jednoznacznej podstawie prawnej28. Przepisy ustalające sankcję muszą być zatem jasne i dokładne, by zainteresowane osoby mogły poznać jednoznacznie swoje prawa i obowiązki, które z niego wynikają i w konsekwencji podjąć odpowiednie działania ${ }^{29}$.

Omawiana sprawa C-369/09 SGS Belgium, dotycząca podstawy prawnej upoważniającej organ krajowy do nałożenia kary pieniężnej na spółkę SGS Belgium za poświadczenie nieprawdy, w wyniku czego eksporter - firma Derwa bezprawnie uzyskała refundację wywozową, zakończyła się rozstrzygnięciem, że podstawy takiej ustanowiły przepisy unijne. Trybunał uznał tak po wykluczeniu, że nie mógł jej stanowić art. 11 rozporządzenia nr 3665/87 (ze względu na zakres podmiotowy ograniczony do eksportera), ani też art. 5 rozporządzenia nr 2988/95 (ze względu na niejasny i niejednoznaczny charakter). TSUE stwierdził przy tym, że ze względu na bezprawne uzyskanie przez eksportera refundacji wywozowej, sankcja finansowa, o której stanowi art. 11 rozporządzenia $\mathrm{nr}$ 3665/87, orzekana na podstawie jego obiektywnej odpowiedzialności, niewymagającej przypisania mu jakiekolwiek postaci winy (umyślnej lub nieumyślnej) powinna być nałożona na eksportera firmę Derwa. Następnie jednak kwota uiszczona przez nią tytułem tej kary może być odzyskana od spółki SGS Belgium, na podstawie przepisów krajowych przewidujących solidarną odpowiedzialność spółki wyspecjalizowanej w płaszczyźnie międzynarodowej w dziedzinie kontroli i nadzoru za finansowe skutki wystawianych przez nią świadectw. Wymaga to jednak stwierdzenia przez sąd krajowy, że przepisy te są jasne i jednoznaczne.

\section{Zakończenie}

Z przedstawionych przepisów i orzecznictwa TSUE wynika, że w przypadku braku przepisów sektorowych, przyjętych w ramach poszczególnych polityk UE, art. 4 rozporządzenia nr 2988/95 stanowi właściwą i wystarczającą podstawę prawną dla odzyskiwania funduszy UE wydatkowanych z naruszeniem prawa. Ustalony w tym rozporządzeniu art. 5, zawierający katalog kar administracyjnych, nie może natomiast stanowić podstawy prawnej ich nakładania, ze względu na jego niejasny i niejednoznaczny charakter. Trybunał uzasadnił ten pogląd odwołując się do zasady ustawowej określoności czynów zabronionych i kar, która wymaga, by przepisy ustalające sankcję były jasne i jednoznaczne, by zainteresowane osoby mogły poznać swoje prawa i obowiązki, a w konsekwencji podjąć odpowiednie działa-

28 Wyroki Trybunału: z dnia 13 grudnia 2012 r. w sprawie C-670/11 FranceAgriMer (niepublikowany), pkt 50; z dnia 14 grudnia 2000 r. w sprawie C110/99 EmslandStärke, ECR s. I11569, pkt 56; z dnia 11 lipca 2002 r. w sprawie C210/00 Käserei Champignon Hofmeister, ECR s. 16453, pkt 52; z dnia 6 kwietnia 2006 r. w sprawie C274/04 ED \& F Man Sugar, Zb. Orz. s. I3269, pkt 15. Wyrok Sądu Pierwszej Instancji z 27 września 2006 r. w sprawie T-43/02 Jungbunzlauer, Zb. Orz. 2006, s. II3435; pkt 71-73 i 75-81. 
nia. $Z$ orzecznictwa tego wynika, że ze względu na zasadę ustawowej określoności czynów zabronionych i kar, podstawą prawną kar nakładanych na jednostki przez organy krajowe za uchybienia przez nie przepisom unijnym mogą być tylko takie przepisy rozporządzeń unijnych, które są jasne i jednoznaczne, a wymóg ten powinien być przestrzegany niezależnie od charakteru prawnego orzekanych kar. 


\section{SANCTIONS FOR IRREGULAR SPENDING OF EUROPEAN UNION FUNDS - LAW AND CASE - LAW REQUIREMENTS}

This article deals with the requirements of EU law and its interpretation by the Court of Justice of the European Union (CJEU) concerning sanctions applied by national authorities when EU funds are spent irregularly. It focuses on two legal issues. Firstly, on the legal basis applied to recover funds spent illegally. In this area, it is vital to identify the legal nature of recovery obligation, which, as the CJEU accepts, is not a penalty. Secondly, it concentrates on the legal basis applied to impose administrative penalties, which, according to the Union's courts, as the principle of legality of offenses and penalties requires, must be clear and precise despite the legal nature of the sanction to be applied.

Keywords: sanction, penalty, recovery of funds, irregularity, infringement of law, Common Agricultural Policy, cohesion policy, legal basis 